in their original article (4 December 1971, p. 593): "Haemoglobin studies later showed that she was a sickle-cell trait carrier" could now be reconciled with the statement in their letter that "the available haematological investigations have not excluded a diagnosis of sickle-cell disease." Your readers, especially those from Africa, would want to know how a Ghanaian nurse said to have needed laparotomy for intestinal infarction after the brief 45-minute flight from Kumasi to Accra was said by the authors to have the "sickle-cell trait" in one article only to be told in their next communication that the diagnosis of sickle-cell disease was not excluded. Their original article with the sickle-cell trait intestinal infarction story was promptly quoted not only in The Times $^{1}$ but also in Nature, ${ }^{2}$ and in the case of the former the conclusion of its Science Correspondent was such that Dr. Green and his colleagues found it necessary to write to dissociate themselves from it. ${ }^{3}$

The bulk of the letter of Dr. Green and his colleagues was taken up with "fresh" evidence to prove that the true sickle-cell trait (with more $\mathrm{HbA}$ than $\mathrm{S}$ ) could lead to splenic infarcts in unpressurized aircraft. But the burden of my earlier criticism was that in their article they produced evidence which did not stand the test of scientific scrutiny, the most glaring example of which is the Ghanaian nurse in whom, on the authors' own present admission, sickle-cell disease was not excluded. Your readers, Sir, are interested in scientific truth. I am one of them, and the very least I am entitled to expect is that if evidence obtained from my own country cannot be scientific it should at least be true.-I am, etc.,

F. I. D. KoNoteY-AHULU Department of Medicine and Therapeutics, Unive-sity of Ghana Me tical School,

Korle Bu Teaching Hospital,

Accra

1 The Times, 9 Deremter 1971. 2 Natue. 1971, 234. 326.
3 Green, R. L., Huntsman, R. G., and Serjeant,
G. R., The Times, 8 February, 1972.

\section{Smoking and Vascular Disease}

SIR,-Your leading article (1 April, p. 3) states unequivocally, "The medical profession is the only professional group in which cigarette smoking has lessened," without the support of any references. I would doubt if each and every professional group has been adequately sampled and reported on. Smoking and Health Now 1 reports that after the publication of the 1962 report there was a sharp reduction in the number of men smoking cigarettes, a reduction maintained in social classes I, II, and III. The professional groups fall in these classes.

Your article goes on to point out that Pozner and Billimoria ${ }^{2}$ (in a small selected sample) found that "fasting plasma turbidity, cholesterol, and $\beta$ and pre- $\beta$ lipoproteins were significantly increased in heavy smokers," but you failed to make the most important point that in male heavy smokers only pre- $\beta$ lipoprotein means were significantly higher than those of non-smokers. In a sample of 2,483 middle-aged males Howell ${ }^{3}$ failed to find significant correlation between smoking and haemoglobin, E.S.R., serum cholesterol, $\beta$ lipoprotein, and uric acid levels. The one striking findingnamely, a significantly increased white blood cell count in heavy smokers-has now been confirmed by Corre, Lellouch, and Schwartz. ${ }^{4}$ In some small way this may provide confirmation that the sample used by Howell was not atypical for males of that age group with an average smoking history extending over 20 years. - I am, etc.,

R. W. HOWELL

\section{Tilehurst, Berks}

moking and Health

Royal College of Physicians, Smoki
Now. London, Pitman, 1971

2 Pozner, H., and Billimoria, J. D., Lancet, 1970, 3 Howell, R. W., Lancet, 1970, 2, 152

4 Corre, F., Lellouch, J., and Schwartz, D., Lancet, $1971,2,632$.

SIR,-I would agree with your leading article (1 April, p. 3) that the case against cigarette smoking in peripheral vascular disease is a very strong one. I am sorry that you take exception to my finding 1 fewer than $1 \%$ of male non-smokers among those seen with lower limb ischaemia. The figure that you quote, of less than $5 \%$, is not strikingly different from mine. Perhaps the disparity may be due to my criterion of a non-smoker's status in this respect: these people were lifelong non-smokers and not ex-smokers. It has been interesting to review the final diagnosis in some of these cases. Entrapment of the popliteal artery, cystic adventitial disease, attrition over an exostosis, as well as other non-vascular causes have been suspected and mostly confirmed on the leading evidence of the non-smoker's status.

There is most certainly the need for more careful review of the relationship between cigarette smoking and occlusive arterial disease in the lower limbs. References are few, indeed you have given most of them.I am, etc.,

London W.1

1 Eastcott, H. H. G., Arterial Surgery. London,

\section{Recurrent Urinary Infections in a Girl}

SIR,-I read with interest the warm flow of correspondence between Drs. Andrew Smith and Hugh Jackson (12 February, p. 428), and the latter's observation that the chief shortcoming to the accurate diagnosis of urinary tract infection, in the early agegroup cited, was the practical difficulty of proving conclusively that bacteria were multiplying within the urinary tract itself. In sympathy with the above writers, to be sure, are the experiences of many in the past that false positive cultures on voided urines from neonates, infants, and children may exceed $60 \%$, even when collections are achieved by the bag or mid-stream techniques done under trained supervision. ${ }^{1}$ No mention, however, of the established technique of obtaining urine by suprapubic bladder aspiration was proferred by $\mathrm{Dr}$. Jackson or Dr. Smith; nor did there once appear in their stream of thinking a single drop of support for this widely used, simple, safe, efficient, and economical procedure.1-5 Hopefully, this exclusion will not retard the rapidly growing appreciation for suprapubic aspiration, which eliminates both the necessity for frequent voided urine collections and also quantitation of the bacterial content of these specimens, with the delays attendant in making a definitive diagnosis. Their omission was all the more astonishing, since suprapubic aspiration relieves general practitioners of the urgency for specimen culture, the aspirated specimens can be safely posted to the laboratory, and the chief problem noted by Dr. Smith, namely that of contamination, has been eliminated. 23

To direct the question of "proven bacteriura" back into mainstream thinking, it is my view that the first such episode in neonates, infants, or children should lead to both an intravenous pyelogram and a micturating cystourethrogram being performed, precisely because up to $50 \%$ of such patients with bacteriuria, symptomatic or not, have been shown to have vesicoureteric reflux. ${ }^{5-7}$ In his letters, Dr. Jackson made insufficient mention of the degree of reflux present in his patient, but presumably because the pelvicalyceal systems had become distended with contrast medium the reflux could be termed "gross" by the criteria of Rolleston et al. ${ }^{6}$ - the only degree of reflux apparently associated with progressive renal damage (occasionally regardless of whether there is coexisting infection).

Dr. Smith's experience with ampicillin provides additional minimal evidence for condemming the use of this drug for the treatment of urinary tract infections, prior to availability of sensitivities of the given pathogens. The place of ampicillin as the drug of general convenience should be seriously questioned, as was strongly suggested by the large multicentre study in the United Kingdom where the sensitivities of over 23,000 different urinary tract pathogens were evaluated: in both inpatient (particularly) and outpatient isolates ampicillin dribbled in a mediocre fourth behind the "big three"-nitrofurantoin, trimethoprimsulphamethoxazole combination, and nalidixic acid. 8

Finally, nitrofurantoin is undoubtedly a useful agent in the prevention of recurrent urinary tract infections, but in a 2-year-old girl a dose of $25 \mathrm{mg}$ t.d.s. would seem excessive, particularly when it has been shown by Professor de Wardener's group ${ }^{9}$ that a single nightly $50 \mathrm{mg}$ dose was very effective in preventing recurrent urinary tract infections in adult women. The dose of drug used by Dr. Smith and Dr. Jackson could reach toxic levels in the serum if the child had coexisting renal functional impairment (which the urea estimation of $50 \mathrm{mg} / 100 \mathrm{ml}$ suggests); moreover, if the child's glomerular filtration rate is less than about $60 \mathrm{ml} / \mathrm{min} /$ $1.73 \mathrm{~m}^{2}$, the drug may not be attaining adequate antibacterial concentrations in the urine. ${ }^{10}-\mathrm{I}$ am, etc.

Renal Unit, Victoria Hospital

Ross R. BaILEY

and Department of Medicine,

Unive:sity of Weste:n On
London, Ontario, Canada

1 Shannon, F. T., Sepp, E., and Rose, G. R., Australian Paediatric fournal, 1969, 5, 97. R., fournal, 1969, 1, 293

3 Bailey, R. R. and Little, P. J., in Renal Infection and Renal Scarring, ed. P. Kincaid-Smith, and K. F. Fairley, p. 81 Melbourne, Mercedes Publishing Services, 1971.

Pott, G. D.. and Shannon, F. T., Clinical Abbott, G. D., British Medical foumal, 1972, 1. 267

6 Rolleston, G. L., Shannon, F. T. and Utley, 7 Kunin, C. M., in Renal Infection and Renal Scarring, ed. P. Kincaid-Smith, and K F. F.
Fairley. p. 287. Melbourne, Mercedes Publish-

ing Services, 1971. Fournal, Sept. A., et al... Postgradua

Fournal, Sept. suppl., 1971, 47. 7. de Wardner, H. E, Lancet, 1971 , , 1112. Sachs, J., Geer, T., Noell, $\mathrm{P}_{\text {New }}$ and Kunin, C. M., 1032. 